RESENHA

\title{
RESENHA DO LIVRO BRICS E 0 FUTURO DA ORDEM GLOBAL
}

STUENKEL, Oliver. BRICS: e o futuro da ordem global. 1. ed. Rio de Janeiro/São Paulo: Paz\&Terra, 2017.

\section{Brendon Lucas Pereira Silva ${ }^{1}$}

O conceito do acrônimo BRICs foi formulado pelo economista-chefe da Goldman Sachs (uma das principais empresas globais de banco de investimento) Jim O'Neill em seu ensaio chamado "Building Better Global Economic $B R / C S^{\prime \prime}$, publicado em 2001 com a intenção de atrair investidores transnacionais para as economias em ascensão. O'Neill criou uma categoria na qual inseriu os países de grande território e em rápido desenvolvimento que economia global. A transformação do termo BRICs de uma categoria de investimentos para um termo familiar na política internacional é um dos desenvolvimentos mais marcantes da política internacional da primeira década do século 21.

Nesta obra, Oliver Stuenkel analisa em detalhes as origens do grupo, seus arranjos cooperativos e ambições visando ser um material de estudo tanto para acadêmicos, como para aqueles que têm interesse na condução da política externa de cada um dos países do BRICs. O livro é organizado em oito capítulos; os três primeiros capítulos uma apresentam a criação do BRICs e suas cúpulas anuais; o quarto explora a inclusão da África do Sul como sinal de amadurecimento do grupo; o quinto cobre as várias áreas

${ }^{1}$ Graduando em Ciências Sociais pela Universidade Federal Fluminense (UFF). de cooperação existentes entre os BRICS; o sexto lida com as iniciativas mais recentes do grupo; o sétimo trata das posições dos países do BRICS sobre soberania e intervenção 
humanitária; o oitavo faz reflexões sobre o BRICS e o futuro da ordem global.

Com a premissa de que a predominância dos EUA como definidora da ordem global fosse ser superada por países com mercados emergentes, o BRICS foi ganhando força. E ao longo da década, a liberalização econômica desses países começou a dar frutos e o poder ilimitado dos Estados Unidos parecia estar chegando ao seu limite com os embates dispendiosos no Iraque e no Afeganistão, justificado pela "guerra ao terror", o que reduziu a legitimidade dos EUA e abriu uma janela de oportunidade para que os países emergentes ganhassem maior visibilidade. E com base nessa narrativa, Oliver Stuenkel caracteriza a primeira década do século 21 como uma transferência de poder dos Estados Unidos e Europa para os países emergentes, como o Brasil, a China e a Índia.

Em 2008, enquanto os países emergentes desfrutavam de uma relativa estabilidade econômica, uma crise financeira atingiu profundamente os países desenvolvidos. E com a crise de legitimidade na ordem financeira internacional, o grupo dos BRICs ganhou um grande poder de barganha temporário que foi convertido em forças capazes de definir a agenda política da época, o que resultou em acordos da reforma de cotas do FMI em 2010.

Neste mesmo ano, a África do Sul foi convidada pelos ministros de relações exteriores do grupo dos BRICs para participar do grupo. O convite decorreu de motivos majoritariamente políticos, como por exemplo, pela África do Sul representar um continente inteiro com uma população de mais de um bilhão de habitantes e pelo fato de o país possuir uma reputação pelo legado positivo da transição do apartheid para a democracia. Com a participação da África do Sul, os BRICs se transformam em BRICS, e ser um membro do BRICS implica um grau considerável de reconhecimento social perante as grandes potências.

Mais à frente no livro, nos deparamos com profundas diferenças culturais e sociais entre os países do BRICS. Dentre essas diferenças podemos destacar principalmente o aspecto do regime político: enquanto Brasil, Índia e África do Sul possuem democracias vibrantes, Rússia e China possuem regimes autoritários. Entretanto, mesmo com essas diferenças, diversas áreas foram beneficiadas pela cooperação 
técnica intra-BRICS, como por exemplo a facilitação do comércio, agricultura, estatísticas e até mesmo fóruns empresariais, do judiciário e da defesa.

Nos encontros da $4^{a}$, $5^{a}$ e $6^{a}$ cúpulas do BRICS em Nova Déli, Durban e Fortaleza, os líderes do BRICS decidiram fundar o Novo Banco de Desenvolvimento do BRICS (NBD) e um Arranjo Contingente de Reservas (ACR), os quais firmariam elos sem precedentes entre os governos para os cinco Estados-Membros. A criação do NBD e do ACR foi um grande marco para o BRICS e pode ser interpretado como a etapa inicial de uma cooperação financeira institucionalizada, pois até 2014 o BRICS era marcado por sua falta de normas vinculativas.

Sobre o Conselho de Segurança da ONU, é levantado o debate acerca da "Responsabilidade de proteger" (R2P). A R2P é divido em três pilares: i) Estados têm a responsabilidade primária de proteger suas populações contra genocídio, crimes de guerra, limpeza étnica e crimes contra a humanidade ; ii) a comunidade internacional tem o compromisso de fornecer assistência aos Estados em criar capacidade para proteger suas populações contra genocídio, crimes de guerra, limpeza étnica e crimes contra a humanidade e para dar assistência aos afetados antes que irrompam crises e conflitos; iii) a comunidade internacional tem a responsabilidade de prestar "ações rápidas e decisivas" a fim de prevenir e combater atos de genocídio, limpeza étnica, crimes de guerra e crimes contra a humanidade quando um Estado fracassar "manifestamente" em proteger suas populações (2017, p. 210-211).

A perspectiva das potências emergentes acerca do primeiro pilar é positiva, pois fortalece os agentes estatais nos assuntos internacionais. Sobre o segundo pilar, a maioria dos países do BRICS está ativamente envolvida no combate às principais causas de genocídio, crime de guerra, limpeza étnica e crimes contra a humanidade. A Índia vem dando contribuições humanitárias imensas às missões de pacificação da ONU há décadas e a China contribui para promover o desenvolvimento e a paz no exterior, através de sua liderança na pacificação e auxílio para desenvolvimento (2017, p. 211). Na perspectiva do BRICS, o terceiro pilar é indeterminado e aberto, assim representando um risco de que as potências ocidentais podem 
interpretar de forma equivocada e estender a norma para além do aceitável.

Concluindo, a cooperação entre países do grupo BRICS vem se ampliando desde 2009, e a parcela do PIB global representada pelo grupo do BRICS deverá aumentar ainda mais nos próximos anos. É interessante compreender a ascensão do grupo do BRICS no contexto do padrão cíclico de mudança sistêmica. Segundo Xiaoyu Pu e Randall L. Schweller no artigo "After Unipolarity: China's Vision of International Order in an Era of U.S. Decline" há cinco fases desse ciclo continuamente recorrente: ele começa com uma ordem estável, em que uma potência hegemônica está no controle do sistema global. A segunda fase é a de desconcentração e deslegitimação do poder da potência hegemônica. A terceira fase é a formação de alianças entre as potências em ascensão como meio para enfraquecer a hegemonia. A quarta fase é a da resolução da crise internacional, via guerra hegemônica, ao que se segue uma quinta fase, a renovação do sistema e o estabelecimento de uma nova ordem, assim voltando à primeira fase.

Embora as Cúpulas do BRICS possam ser entendidas como um exercício de deslegitimação da ordem global, não existe nenhum indicativo evidente de que os membros do BRICS estejam interessados em adotar medidas tangíveis para comprometer a ordem global.

Um dos pontos altos da obra é que todas as informações nela são contextualizadas, há uma profunda preocupação do autor em detalhar cronologicamente cada evento do livro. Outro ponto alto em sua estruturação é que no início de cada capítulo, logo após ele introduzir o assunto, é colocado diversas citações de críticos ao BRICS, e ao longo do capítulo ele contra-argumenta os críticos utilizando dados concretos, e muitas das vezes demonstrando que o BRICS é muito mais do que um bloco econômico, é um bloco político.

"BRICS e o futuro da ordem global" é uma excelente leitura para todos aqueles que querem conhecer o BRICS e sua "biografia histórica". Oliver Stuenkel fez um excelente trabalho ao reunir informações das mais diversas fontes ao longo de todo o processo de criação do BRICS, e aliou isso com uma narrativa fluída e dinâmica, sempre fazendo o leitor questionar diversos pontos, e apresentando 
críticas de opositores ao BRICS com o intuito de debater e contraargumentar. Uma leitura imprescindível para todos aqueles que buscam estar a par da política internacional. 